Julian Jeliński

\title{
POWSTANIE RELIGII \\ W ŚWIETLE ANTROPOLOGII \\ I PSYCHOLOGII KOGNITYWNEJ. KONCEPCJA PASCALA BOYERA
}

Różnorodność wierzeń religijnych wciąż zaskakuje nawet najbardziej zagłębionych w poznawanie tego fenomenu badaczy. Zaskakuje także mnogość praktyk odzwierciedlających relacje między najróżniejszymi bóstwami a człowiekiem - od pełnego „oddania” bóstwom, poprzez „współpracę” z nimi, aż po próby ich „oszukania” (ciekawe, że rzadko natrafia się na świadome „ignorowanie” bóstw). Wiele pojawiło się już teorii i prób sformułowania odpowiedzi, które miałyby wyjaśnić przyczynę istnienia tych relacji oraz różnorodności wierzeń. Wśród nich także odpowiedź najprostsza, znosząca sens jakichkolwiek badań (choć przecież wciąż możliwe, że słuszna), uznająca jakąś religię za prawdziwą i odzwierciedlającą porządek ontologiczny.

Zawieszając chwilowo pytanie o istnienie bytów nadprzyrodzonych, wciąż pozostaje kwestia wierzeń ludzi, które stanowią niezwykle ciekawy przedmiot badań. Idealnie wpisuje się to w rozumienie religii jako zjawiska naturalnego, które kilka lat temu zaproponował Daniel Dennett ${ }^{1}$.

Dla Dennetta:

${ }^{1}$ Zob. D. Dennett, Odczarowanie. Religia jako zjawisko naturalne, przeł. B. Stanosz, PIW, Warszawa 2010. 
Religie należą do najpotężniejszych zjawisk naturalnych na tej planecie i musimy lepiej je zrozumieć, jeśli chcemy podejmować kompetentne i sprawiedliwe decyzje polityczne. Narazimy się wprawdzie na pewne związane z tym ryzyko i dyskomfort, lecz powinniśmy zebrać siły i odłożyć na bok naszą tradycyjną niechęć do rozważania zjawisk religijnych w naukowy sposób po to, by zrozumieć, jak i dlaczego religie inspirują ludzi do tak wielkich poświęceń, oraz ustalić, jak należy radzić sobie z nimi wszystkimi w XXI wieku².

Zgodnie z tym programem, niezależnie od tego, czy istnieje jeden Bóg, czy wielu bogów, „sama religia, jako złożony zbiór faktów, jest absolutnie naturalnym zjawiskiem" 3 . Dlatego też stawianie pytań dotyczących religii nie musi automatycznie być stawianiem pytań ontologicznych i podważaniem prawdziwości samych wierzeń religijnych. Zdaniem Dennetta może być wręcz odwrotnie, gdyż ,jedyna szansa udowodnienia tego [prawdziwości religii i rzeczywistości cudów - J.J.] wątpiącemu światu polega na posłużeniu się metodą naukową, z jej założeniem o nieistnieniu cudów, i wykazaniu, że nauka jest jawnie niezdolna do wyjaśnienia owych zjawisk"4. Przyjmując Dennetta rozumienie religii okazuje się, że stawianie pytań typu: „Dlaczego mamy tak różne wierzenia?”, „Czemu jesteśmy do nich tak mocno przywiązani?”, „Czy istnieją w nich jakieś elementy wspólne, które jesteśmy w stanie rozpoznać?”, „Jakie były początki tych wierzeń?”, „Czy ulegały one zmianom?” - może być nie tylko niezwykle intrygujące, ale wręcz praktycznie potrzebne (zapotrzebowanie to obejmowałoby nie tylko świat nauki, ale i świat polityki).

Celem tego artykułu jest podążenie za przedstawionym wyżej rozumieniem religii jako fenomenu naturalnego i scharakteryzowanie jednej z możliwych odpowiedzi na postawione w powyższym akapicie pytania. $\mathrm{W}$ artykule przedstawiona i poddana analizie zostanie koncepcja francuskiego antropologa Pascala Boyera ${ }^{5}$. Boyer, by udzielić odpowiedzi na pytania o korzenie wierzeń religijnych oraz ich różnorodność, wykorzystuje narzę-

${ }^{2}$ Tamże, s. 53.

${ }^{3}$ Tamże, s. 50.

${ }^{4}$ Tamże, s. 50.

${ }^{5}$ Zob. w internecie: http://artsci.wustl.edu/ pboyer/PBoyerHomeSite/index.html (dostęp: 22 VIII 2011). 
dzia antropologii oraz psychologii kognitywnej. Za podstawę rekonstrukcji koncepcji Boyera posłuży mi jego główne dzieło: I człowiek stworzył Bogów... Jak powstała religia?'. W dalszej części artykułu przybliżone zostaną najważniejsze elementy teorii Boyera, wytłumaczona zostanie terminologia, jaką posługuje się ten autor opisując ludzki umysł, oraz przedstawiona argumentacja, mająca ukazać związek pomiędzy sposobem funkcjonowania ludzkiej pamięci oraz ludzkiego umysłu a istnieniem oraz różnorodnością wierzeń religijnych.

Pascal Boyer, francuski (choć obecnie mieszkający i pracujący w Stanach Zjednoczonych) antropolog zajmujący się między innymi badaniami nad umysłem i procesami uczenia się, przyswajania nowej wiedzy, wykłada na wydziałach psychologii i antropologii Washington University w St. Luis, stara się odpowiedzieć na narzucające się pytania o pochodzenie i korzenie religii.

Boyer w swoich badaniach odwołuje się do wyników badań uczonych reprezentujących takie nauki jak: antropologia, biologia ewolucyjna, psychologia poznawcza czy też lingwistyka. Wykorzystuje te badania, pochodzące $z$ tak odmiennych dziedzin nauki (a nawet badania niedotyczące bezpośrednio religii czy też wierzeń), by spróbować od innej, niestandardowej strony podejść do tematów korzeni i różnorodności wierzeń religijnych, a także spróbować zrekonstruować proces tworzenia oraz zmian wyobrażeń dotyczących świata niematerialnego czy metafizycznego. Stara się również wyjaśnić charakter relacji między człowiekiem a bóstwami (i przyczyny tego stanu rzeczy) odwołując się do tych samych badań.

Mimo że francuski antropolog zajmuje się przede wszystkim wierzeniami grup plemiennych, korzeniami religii i ich różnorodnością, jego perspektywa wydatnie różni się od tej najczęściej u antropologów i etnologów spotykanej. Pozycje, w których przedstawił swoją koncepcję - I człowiek stworzył bogów... Jak powstała religia? oraz The naturalness of religious ideas: a cognitive theory of religion ${ }^{7}$ - nie przypominają słynnej już pozycji Jamesa Frazera - Złota gałazz'. Nie znajduje się w nich wykaz najróżniejszych wierzeń

${ }^{6}$ Zob. P. Boyer, I człowiek stworzył bogów... Jak powstała religia?, przeł. K. SzeżyńskaMaćkowiak, Prószyński i S-ka, Warszawa 2005.

${ }^{7}$ Zob. tenże, The naturalness of religious ideas: a cognitive theory of religion, University of California Press, Berkeley 1994.

${ }^{8}$ Zob. J.G. Frazer, Złota gałaź, przeł. H. Krzeczkowski, PIW, Warszawa 1965. 
religijnych, opis najrozmaitszych praktyk ludów z całego świata. Boyer wielokrotnie odwołuje się do przykładów, jednakże służą mu one jedynie do zaprezentowania swojej koncepcji oraz ukazania sposobu funkcjonowania mechanizmów, które w książkach opisuje. Podstawowym celem nie jest dla niego opisanie, a próba wyjaśnienia wierzeń i zachowań religijnych. Omówieniu realizacji tego celu przez Boyera poświęcona jest dalsza część artykułu.

Mimo że Boyer jest antropologiem, to ażeby odkryć zagadki wierzeń religijnych odnosi się przede wszystkim do badań nad umysłem. Jak podkreśla:

Wyjaśnienia wierzeń i zachowań religijnych szukać należy w mechanizmach funkcjonowania ludzkiego umysłu. Mam na myśli „umysły wszystkich ludzi", a nie tylko wierzących lub niektórych wierzących".

Przyjmując tę perspektywę należy najpierw poddać analizie ludzki umysł - proces zapamiętywania, kojarzenia, rozpoznawania itp. Dopiero lepsze zrozumienie sposobu funkcjonowania ludzkiego mózgu może pozwolić - zdaniem Boyera - na zrozumienie tak niezwykłego fenomenu, jakim jest religia. To tłumaczyłoby także, dlaczego wcześniejsze próby zmierzenia się z tym fenomenem nie mogły się powieść. Nie mogły, gdyż psychologia kognitywna, neuropsychologia, a także zaawansowane badania nad ludzkim mózgiem - to stosunkowo nowe dziedziny nauki, które dopiero od kilkunastu/kilkudziesięciu lat się rozwijają.

Poddając więc analizie umysł zauważa się, że w niczym nie przypomina on ani tabula rasa, na której odciskają się doświadczenia, ani też encyklopedii, którą stopniowo wypełniamy kolejnymi hasłami. Niezwykle istotne jest też zauważenie, że:

Żaden umysł [...] nie może niczego się nauczyć, jeżeli nie dysponuje już na początku drogi [poznawania - dop. J.J.] narzędziami pozwalającymi mu trafnie rozpoznać informacje dostarczane przez otoczenie, a następnie poddać je swoistej obróbce ${ }^{10}$.

${ }^{9}$ P. Boyer, I człowiek..., dz. cyt., s. 10. Ale trzeba pamiętać, że: „nie można liczyć na to, że zdoła się zrozumieć naturę religii, ograniczając się do spekulacji na temat funkcjonowania mózgu": tamże, s. 36.

${ }^{10}$ Tamże, s. 11. 
Dlatego tė̇:

[...] umysł przyswajający wiedzę nie jest pustym kontenerem, do którego doświadczenie i edukacja wrzucają na pół przetrawione informacje. Potrzebuje on metody porządkowania informacji, umożliwiającej nadawanie sensu temu, co zaobserwował i czego się nauczył i na ogół ją ma. Pozwala mu to wykraczać poza zdobyte informacje, czyli - używając terminologii psychologów, dokonywać dedukcji dzięki wykorzystaniu zebranych informacji $1^{11}$.

Tym, dzięki czemu jesteśmy w ogóle w stanie poznawać świat zewnętrzny, jest wyspecjalizowany zestaw mechanizmów, zwanych systemami kojarzeniowymi, „z których każdy jest dostosowany do obróbki określonego typu informacji i automatycznie podsuwa ich wyjaśnienie"12. Co istotne proces wyjaśniania nie jest procesem świadomym, ze względu na swoją szybkość oraz intuicyjność, a co gorsza, nie możemy go zaobserwować poprzez introspekcję. Sytuację tę dobrze opisuje przywołany przez autora przykład „kartezjańskiego teatru” używany przez Daniela Dennetta. Dennett opisuje złudzenie polegające na tym, iż wydaje się nam, że to, co dzieje się w naszych mózgach, jest świadomym rozumowaniem (stąd odniesienie do cogito). Jednak za tym świadomym myśleniem (lub też niejako „pod nim”) odbywają się procesy, których nie jesteśmy świadomi i które odsłaniają się nam dopiero dzięki badaniom nauk kognitywnych ${ }^{13}$.

Systemy skojarzeniowe pomagają klasyfikować i szeregować bodźce dochodzące do nas ze świata zewnętrznego, porządkować informacje, które otrzymujemy i nabywamy. Nie znaczy to jednak, że owo „porządkowanie” ma charakter encyklopedyczny. Ten proces znacznie bardziej przypomina dopasowywanie nowo nabytych doświadczeń do konkretnych schematów pojęciowych, które przypominają formularze, „w których wypełniamy rubrykę po rubryce" ${ }^{14}$. Schematy pojęciowe nie mogą być rozumiane jako

${ }^{11}$ Tamże, s. 47.

${ }^{12}$ Tamże, s. 24.

${ }^{13}$ Zob. tamże, s. 25 (Dennett sformułował hipotezę „teatru kartezjańskiego” w dziele Consciousness Explained, zob. D.C. Dennett, Consciousness Explained, Little, Brown \& Co, Boston 1991, s. 106-107.

${ }^{14}$ Tamże, s. 47. 
hasła encyklopedyczne. Przede wszystkim „schematów pojęciowych jest mniej niż samych pojęć”, a także „są bardziej abstrakcyjne od pojęć i służą ich konstruowaniu” ${ }^{15}$. Najlepiej zdefiniować je jako ,jedno z narzędzi umożliwiających mózgowi ludzkiemu wytworzenie jednakowych wyobrażeń, nawet jeżeli droga przekazu nie jest doskonała"16.

Owo konstruowanie pojęć polega na umiejętności dedukcji cech z przynależności pojęcia do bardziej ogólnych kategorii. Nie wszystkie pojęcia są bowiem takie same i różnią się między innymi stopniem abstrakcji. Te najogólniejsze, takie jak osoba, liczba, artefakt czy zwierzę, nazywa Boyer „kategoriami ontologicznymi”, czyli takimi kategoriami, które w sposób najbardziej ogólny charakteryzują rzeczy, a z nich można wyodrębniać pojęcia bardziej konkretne. Kategorie te nie stanowią odrębnych bytów, a nawet sztywnych i domkniętych zbiorów:

[...] błędem jest mówienie o „kategoriach ontologicznych”, jakby chodziło o obiektywną rzeczywistość, ponieważ wiele obiektów przechodzi z „kategorii” do „kategorii”, w zależności od podejścia do nich ${ }^{17}$.

Kategorie ontologiczne to schematy pojęciowe; „obejmują wszelkiego rodzaju dedukcje zaoczne, ułatwiające nam przyswojenie nowego pojęcia [...]"18. Dedukcja zaoczna polega na wywnioskowaniu (ale nie na świadomym wnioskowaniu) cech pojęcia z jego przynależności do jakiejś kategorii ontologicznej. Na przykład gdy dowiemy się, że żyrafa to zwierzę, to dedukcja zaoczna doprowadzi do tego, że będziemy jednocześnie wiedzieć, że z żyraf powstają inne żyrafy, że każda żyrafa jest (mniej więcej) taka sama „w środku”, że żyrafa musi jeść, rozmnażać się itd. To właśnie tego typu procesy pozwalają nam kumulować wiedzę w praktyczny sposób.

Jak wynika z powyższego opisu, poznawanie na poziomie mózgu nie jest procesem przypadkowym i nieograniczonym formalnie. Sytuacja przedstawia się podobnie w przypadku wyobraźni. Metody porządkowania informacji ograniczają też naszą wyobraźnię.

\footnotetext{
${ }^{15}$ Tamże, s. 49.

${ }^{16}$ Tamże, s. 50.

${ }^{17}$ Tamże, s. 102.

${ }^{18}$ Tamże, s. 63.
} 
[...] wyobraźnia ludzka nie działa na zasadzie „pełnej dowolności” i nie oddaje się intelektualnym grom, w których wszelkie kombinacje myślowe byłyby równouprawnione, a umysł dowolnie wykraczałby poza wyznaczone ramy. Przeciwnie, wyobraźnię mocno ograniczają takie struktury ${ }^{19}$.

W związku z tym, że pojęcie „kategorii ontologicznych” opisuje przedmioty, nie zaś proces, a to właśnie proces zachodzący w naszym mózgu jest tym, co pozwala nam poznawać, Pascal Boyer zastępuje kategorie listą systemów właściwych skojarzeń. „Jeśli jakiś obiekt aktywuje systemy fizyki intuicyjnej i wykrywania celów, a także pewne oczekiwania biologiczne, [...] to obiekt nazywamy «zwierzęciem». [...] Zamiast myślowej encyklopedii teoretycznych deklaracji na temat tego, czym są zwierzęta, osoby, narzędzia itd., dysponujemy po prostu tropami, które aktywują pewne systemy, a wyłączają inne"20. Podsumowując rozważania stanowiące klucz do odpowiedzi na pytania o korzenie wierzeń religijnych i ich różnorodność, Pascal Boyer jasno argumentuje, dlaczego powinniśmy podchodzić do ludzkiego umysłu w sposób, który antropolog proponuje i został scharakteryzowany powyżej:

Opis naszego umysłu jako wiązki systemów kojarzeniowych jest trafniejszy od koncepcji encyklopedii umysłowej, ponieważ dokładniej odpowiada strukturze mózgu. W mózgu nie istnieje przecież „rozumowy katalog wszelkich istniejących rzeczy”, nie znajdziemy w nim też podziału na sektory, które zajmują się zwierzętami lub osobami albo koncentrują się tylko na wytworach ludzi itd. Znajdziemy tam natomiast ogromną ilość systemów kojarzeniowych, które wytwarzają różnego rodzaju skojarzenia odnoszące się do rozmaitych aspektów naszego otoczenia. Nie są to tylko teoretyczne spekulacje - istnienie takich systemów i ich ścisła specjalizacja zostały ujawnione dzięki technikom obrazowania oraz pracom anatomopatologów ${ }^{21}$.

Podchodząc do umysłu w ten sposób zauważamy, że to nie „prawdziwość” danej idei jest dla ludzkiego umysłu najważniejsza. Proces przyswajania idei czy też informacji przebiega inaczej:

\footnotetext{
${ }^{19}$ Tamże, s. 64.

${ }^{20}$ Tamże, s. 101.

${ }^{21}$ Tamże, s. 102-103.
} 
Idee, które najsilniej „pobudzają” systemy kojarzeniowe, lepiej przystają do naszych oczekiwań i wyzwalają bogate skojarzenia, łatwiej i częściej są przyswajane i przekazywane. Nie dlatego przyjmujemy jakieś idee, że są nasze albo sensowne czy przydatne, lecz dlatego, że konstrukcja naszego mózgu uniemożliwia nam uchylenie się od ich przetworzenia ${ }^{22}$.

Mając na uwadze informacje o tym, w jaki sposób ludzki umysł porządkuje doświadczenia, możemy przejść do problemu wierzeń religijnych. Pierwszym pytaniem, na które musimy odpowiedzieć, jest pytanie o sposób, w jaki Boyer rozumie religię i wierzenia. Czy jego rozumienie tego fenomenu przypomina Durkheimowskie, Weberowskie, czy może formułuje oryginalną definicję? Jako antropolog, Boyer poszukuje wspólnych cech religii. Wspólnych cech szukało przed nim wielu, ale zdaniem francuskiego badacza nie zdołało ich odnaleźć (albo dostarczyło tylko częściowo prawdziwej odpowiedzi). Większość teorii owych wspólnych cech religii najczęściej upadała, gdy antropolodzy znajdywali przykłady wierzeń, w których owa cecha nie występowała. Było tak ponieważ poszukiwania naukowców i badaczy koncertowały się na przedmiocie wierzeń:

Wszyscy wychodzili z założenia, że religia jako taka musi mieć związek z sacrum, z boskością, z wyższą prawdą, a nawet, co dziwniejsze że wszystkie religie nawiązują do słońca, planet, krwi, lęku przed ojcem lub kultu przyrody. Jednak kultura ludzka jest zjawiskiem znacznie bardziej skomplikowanym ${ }^{23}$.

Jednak różnorodność wierzeń jest:

[...] zjawiskiem znacznie głębszym, przejawiającym się w sposobie postrzegania istot nadprzyrodzonych, wyobrażania sobie ich wyglądu i sposobu działania, w moralności wynikającej z przekonań religijnych, w rytuałach, obrzędach i w wielu innych dziedzinach życia ${ }^{24}$.

Boyer ponadto zwraca uwagę, że do religii (zespołu wierzeń religijnych) powinniśmy zaliczyć także te wierzenia, których nie określa się mianem

\footnotetext{
${ }^{22}$ Tamże, s. 164.

${ }^{23}$ Tamże, s. 60.

${ }^{24}$ Tamże, s. 15.
} 
religii. Francuski antropolog podkreśla, że termin „religia” stanowi jedynie „praktyczną etykietę”, której używamy w celu opisu wszystkiego (zachowań, poglądów, wierzeń, norm, postaw), co „odnosi się do sposobu istnienia i właściwości bytów nadprzyrodzonych, takich jak Bóg”"25. Sam fakt, iż termin „religia” nie istnieje w języku danej grupy, nie oznacza przecież, że nie pojawiają się odniesienia do bytów nadprzyrodzonych. Religia staje się więc niezwykle szerokim pojęciem, którego centrum stanowi relacja z bytami nadprzyrodzonymi. Przyjęcie takiego rozumienia religii/wierzeń religijnych jest bardzo istotne, ale jednocześnie wydaje się dobrym posunięciem, ze względu na to, iż celem poszukiwań i badań są także tzw. pierwotne wierzenia - korzenie religii, a w tym wypadku nie można mówić np. o instytucjach religijnych.

Nie jest to jednak jedyna charakterystyka wierzeń religijnych dokonana przez francuskiego antropologa. Odnosząc się do podstaw wierzeń Boyer zaznacza, że „religia to przede wszystkim «praktyka»”, oraz że „w rozumowaniu oraz intuicjach znacząca jest pozycja «relacji» z czynnikami nadprzyrodzonymi" ${ }^{26}$. Wyjaśnia, iż ludzie odwołują się do wyobrażeń religijnych prawie zawsze $\mathrm{w}$ sytuacjach, gdy (w jakiś sposób) ich potrzebują. Mogą to być sytuacje, gdy wydarzy się coś „niewytłumaczalnego”, coś niezwykłego, coś poruszającego. Wierzenia religijne nie powstały jako ogólne teorie, a jako sposób podejścia do konkretnych wydarzeń. Kwestia „relacji” do nadprzyrodzoności jest równie ważna. Działanie istoty nadprzyrodzonej, które nie ma nic wspólnego z życiem ludzi, na które nie da się wpłynąć, nie miałoby sensu. Wiara w istnienie bytów nadprzyrodzonych (duchów, bogów, Boga, ale także chociażby zombie) jest ważnym elementem, ale nieodłącznym od wierzenia, że w jakiś sposób można się z tymi bytami kontaktować - wchodzić z nimi w relację.

Kontakt z bytami nadprzyrodzonymi odkrywa jeszcze jedną, niezwykle istotną cechę wierzeń religijnych. Nie ma jednego, podstawowego wierzenia dotyczącego wyglądu istoty boskiej. Duchy mogą być duchami ludzi, ale równie dobrze bóstwo może przybrać formę zwierzęcia. Jest jednak pewna cecha, która towarzyszy wszystkim wierzeniom:

\footnotetext{
${ }^{25}$ Tamże, s. 16.

${ }^{26}$ Tamże, s. 139.
} 
[...] bogowie i duchy nie zawsze obdarzani są ludzką postacią, zawsze jednak posiadają ludzką „inteligencję”, która jest ich cechą charakterystyczną. Ludzie wyobrażają sobie, że istoty nadprzyrodzone postrzegają wydarzenia, myślą i działają intencjonalnie ${ }^{27}$.

Podsumowując: religia przez Pascala Boyera rozumiana jest jako wierzenie $\mathrm{w}$ istnienie bytów nadprzyrodzonych, wytworzone i pojawiające się najczęściej w sytuacjach praktycznych; wierzenie, że z owymi bytami można nawiązać kontakt i działają one intencjonalnie.

Znając sposób definiowania religii przez autora I człowiek stworzył bogów..., możemy zadać pytanie, jak wiedza o funkcjonowaniu ludzkiego umysłu może pozwolić nam zrozumieć, w jaki sposób wierzenia religijne się pojawiają i zostają przez ludzi przyjmowane jako prawdziwe. Dlaczego ludzkie doświadczenie doprowadziło do stworzenia metafizycznych przekonań i dlaczego przybrały właśnie taki (jak przed chwilą zostało to zdefiniowane) kształt.

Pierwszym wnioskiem Boyera, dotyczącym „tworzenia” idei religijnych, jest zwrócenie uwagi na fakt, że ludzki umysł interpretując codzienne doświadczenia bezustannie tworzy najprzeróżniejsze „wierzenia” i wytłumaczenia. Nie jesteśmy od urodzenia racjonalistami i materialistami. Systemy kojarzeniowe ludzkiego mózgu nie odrzucają automatycznie wszystkich „nieprawdopodobnych” informacji, które uzyskują. Co więcej proces przyswajania informacji nie polega jedynie na ich „przekopiowywaniu” (co zostało już ukazane powyżej) - umysł nieustannie „pracuje” nad informacjami: zmienia ich brzmienie, modyfikuje, rozwija, łączy z innymi itd. Dlatego też powinniśmy przeformułować pytanie: „aby wyjaśnić, czym jest religia, musimy się dowiedzieć, w jaki sposób umysł ludzki, stykający się z różnorodnymi danymi potencjalnie religijnymi, nieustannie redukuje ich ilość" 28 .

Wynika z tego, że zmienia się cel poszukiwań. Tworzenie wierzeń religijnych i przypominających religijne (czyli odwołujących się w jakikol-

\footnotetext{
${ }^{27}$ Tamże, s. 145

${ }^{28}$ Tamże, s. 37 i n.: „Oznacza to, że zawsze, w każdej chwili, nieskończona liczba wariantów idei religijnych powstawała i powstaje w umysłach jednostek. Nie wszystkie te warianty stają się obiektem przekazu kulturowego. To, co nazywamy «zjawiskami kulturowymi», jest wynikiem selekcji, jaka odbywa się zawsze i wszędzie”. Zob. tamże, s. 38.
} 
wiek sposób do ponadnaturalności) okazuje się naturalnym procesem ludzkiego radzenia sobie z otaczającym światem i ludźmi. Problemem zaś pozostaje kwestia, dlaczego pewne typy idei religijnych okazują się najpopularniejsze i są najsilniej reprodukowane przez członków społeczeństwa. Problemem staje się kwestia selekcji, która jednak nie jest procesem świadomym i dokonuje się w umyśle każdego z nas. Ważne w tym miejscu jest podkreślenie, że „uwierzenie” w jakąś ideę religijną nie stanowi dowodu irracjonalności. Jak podkreśla Boyer:

Ludzie są religijni nie dlatego, że każą zamilknąć zdrowemu rozsądkowi oraz krytycyzmowi i akceptują niezwykłe stwierdzenia; każą zamilknąć krytycyzmowi, ponieważ pewne niezwykłe stwierdzenia stały się dla nich oczywiste ${ }^{29}$.

Boyer twierdzi nie tylko, że pewne idee stały się popularniejsze - one były dla ludzi oczywiste, naturalne. Co więcej - nie były przedmiotem wiary, a wiedzy. Wiedzy, że np. duchy obserwują konkretną wioskę i można je w jakiś sposób przebłagać. Oczywistość tych wierzeń jest zdaniem francuskiego antropologa wynikiem istnienia w ludzkim umyśle specyficznych „przepisów”, pozwalających na powstanie pojęć religijnych metodą dedukcji w sytuacjach, gdy podstawą dla takich "wierzeń" stają się osobiste doświadczenia lub też informacje uzyskane od osób trzecich. Ów „przepis” to sposób, w jaki specyficzne wierzenia mogą wchodzić w interakcje z systemami kojarzeniowymi, tak by były łatwo zapamiętywane, szybko uznawane za wiarygodne, swobodnie replikowane i silnie oddziaływały na ludzkie emocje ${ }^{30}$. Eączenie tych cech stanowi o sile i sukcesie idei religijnych.

Postarajmy się opisać idee religijne stosując kategorie, które zostały scharakteryzowane we wcześniejszej części artykułu. Cóż mogą mieć ze sobą wspólnego: osobowy Bóg; duch przodków; ogromny, niewidzialny tygrys krążący nad lasem; góra, która musi być karmiona, by nie ukarać ludzi wybuchem lawy; las, który pozwala ludziom na upolowanie zwierzyny, jeżeli dobrze go traktują i dla niego śpiewają, oraz zombie? Wszystkie te idee

\footnotetext{
${ }^{29}$ Tamże, s. 36.

${ }^{30}$ Zob. tamże, s. 53-54.
} 
opisują nowy typ bytów czy też rzeczy. Nie jest to jednak całkowicie nowy typ. Niewidzialny tygrys to wciąż tygrys, a zombie to poniekąd wciąż człowiek. Jak widać ów nowy typ rzeczy tworzony jest poprzez stworzenie pewnego rodzaju dysonansu poznawczego. Opis rzeczy polega na zwróceniu uwagi na trzy kwestie:

- kategorię ontologiczną przedmiotu;

- cechy, które odróżniają ów przedmiot od innych należących do tej samej kategorii;

- zaprzeczenie części cech, których dostarcza kategoria ontologiczna (część cech, które odróżniają ów przedmiot od innych są sprzeczne z cechami wynikającymi z przynależenia przedmiotu do kategorii ontologicznej) ${ }^{31}$. Podsumowując:

[...] idee religijne zawsze zawierają informacje sprzeczne $\mathrm{z}$ pewnymi oczekiwaniami, wynikającymi z charakteru przywołanej kategorii ${ }^{32}$.

Czy można w jakiś sposób dookreślić owe informacje wyróżniające idee religijne? Czy istnieją jakieś dotyczące ich granice czy też prawidłowości? Otóż okazuje się, że tak. Boyer odwołuje się do wielu badań koncentrujących się nie tylko na religii w wąskim tego słowa znaczeniu, ale na wyobrażeniach świata ponadnaturalnego (czyli także mitów, bajek i tworów wyobraźni). Przywołuje między innymi prace psychologów Franka Keil i Michaela Kelly, którzy ustalili, że:

[...] przeważająca część przemian mitologicznych dokonuje się między bliskimi sobie kategoriami ontologicznymi. Istoty ludzkie częściej zamieniają się w zwierzęta niż w rośliny, częściej w ssaki i ptaki niż w mikroby czy owady; zwierzęta bywają zmieniane $w$ inne zwierzęta lub rośliny częściej niż w martwe twory natury" ${ }^{33}$.

Wnioski z tych wszystkich badań prowadzą do odkrycia znacznej schematyczności działania umysłu nawet w przypadku opisywania sfery zjawisk i istot nadprzyrodzonych. Schematyczność ta objawia się także w kwestii

\footnotetext{
${ }^{31}$ Zob. tamże, s. 65-67.

${ }^{32}$ Tamże, s. 67.

${ }^{33}$ Tamże, s. 69-70.
} 
innych cech istot nadprzyrodzonych. Istota taka zachowuje wszystkie pozostałe właściwe skojarzenia zaoczne dotyczące kategorii ontologicznej, do której przynależy. Przykładowo: duch przodków wyobrażany jest jako byt, który może przenikać przez ściany, jest niewidzialny, stanowi przedmiot, którego cechy zaprzeczają skojarzeniom kategorii „człowiek”. Ale uważa się, że duch przodków wciąż widzi, działa celowo, pamięta i kojarzy fakty, czyli spełnia wszystkie inne cechy, które można wydedukować z kategorii ontologicznej „człowiek”. Obserwacja ta jest bardzo istotna, gdyż wyjaśnia „zrozumiałość” idei religijnych. Spełnianie większości oczekiwań zaocznych systemów kojarzeniowych powoduje łatwość „przyswajalności" takich idei.

Ważne w tym miejscu jest podkreślenie, że cechy, które przeczą przynależności przedmiotu do danej kategorii ontologicznej, są w tej kwestii decydujące. Przeczenie innym intuicjom - dodawanie duchom/bogom rogów, skrzydeł, kopyt, czy też innych tego typu cech - nie podważa kategorii ontologicznej (człowiek z rogami jest dziwnym tworem, ale rogi nie podważają kategorii ontologicznej człowieka). Dlatego też tego typu „szczegóły” zmieniają się znacznie częściej, czasem nawet w przypadku opisu tego samego bytu nadprzyrodzonego (mieszkańcy jednej wioski mogą różnie „ozdabiać” dane bóstwo). Ich mnogość jest jedynie sposobem wzbogacania sprzeczności ontologicznej występującej w opisie istoty.

W tym miejscu znamy już pierwszy element „przepisu na ideę religijną”. Dobra (czyli łatwa do zapamiętania i przekazania innym) idea istoty nadprzyrodzonej powstaje poprzez: 1) opisanie sposobu, w jaki przynależy do wybranej kategorii ontologicznej; 2) następnie dodanie „informacji szczególnej", która kłóciłaby się naturalnymi intuicjami wobec tej kategorii. Podsumowując: to „niespełnienie pewnych intuicyjnych oczekiwań i równoczesne zachowanie pozostałych skojarzeń łącznie wyjaśniają, dlaczego wszystkie wyobrażenia o świecie nadprzyrodzonym są nam tak bliskie" ${ }^{34}$.

Przeprowadzona do tej pory argumentacja nie tłumaczy, dlaczego byty nadprzyrodzone wyobrażane są jako działające intencjonalnie wobec ludzi i dlaczego wierzy się, że można z nimi nawiązać kontakt. To drugie wierzenie po części wynika z pierwszego: $\mathrm{z}$ bytem nieposiadającym inteligencji nie można „negocjować” swojej sytuacji. Odpowiedź na to pytanie znajduje się

\footnotetext{
${ }^{34}$ Tamże, s. 80.
} 
w zrozumieniu „specyficznych wymogów ludzkiej egzystencji”. Człowiek pierwotny był uzależniony przede wszystkim od informacji. Informacji dotyczących kwestii, „czy ten odgłos jest odgłosem nadchodzącego drapieżnika, czy zwierzyny łownej?”, „czy owoce tego krzewu są jadalne?”, „czy mogę zaufać tej jednostce?”, „czy ta jednostka nie ucieknie podczas polowania, gdy potrzebna będzie jego pomoc?" itp. Odpowiedzi na te pytania stanowiły o życiu i śmierci, nic więc dziwnego, że naturalny był proces dedukcji na podstawie najmniejszych nawet skrawków informacji. To też tłumaczy, dlaczego środowisko spełniające warunki niezbędne do życia ludzi zostało przez część antropologów określone mianem „środowiska informacji" ${ }^{\prime 3}$.

Życie zanurzone w świecie informacji prowadzi do bardzo istotnych konsekwencji. Współpraca oraz dostęp do informacji jest ludziom niezbędny. Jednakże nie mamy bezpośredniego dostępu do wszystkich potrzebnych danych (chociażby o zamiarach innych ludzi - czy są wobec nas wrogo nastawieni, czy też przyjaźnie), przez co stajemy się uzależnieni od informacji (prawdziwych, lub błędnych) przekazywanych nam przez innych ludzi. Stopień, w jakim człowiek jest uzależniony od komunikacji z innymi ludźmi, jest znacznie wyższy niż stopień zależności występujący u jakiegokolwiek innego gatunku. W związku z tym, że ludzie są uzależnieni od informacji, potrzebują także danych o innych ludziach, dotyczących ich stanów mentalnych, intencji, wiedzy. Są one niezbędne, by móc funkcjonować w grupie. W związku z tym bezustannie nieświadomie oceniamy sposób, w jaki druga osoba mówi, jak się zachowuje, co mówi itd. Bez tego procesu ludzie nie byliby w stanie przeprowadzić podstawowych czynności, które odbywają się w ramach życia grupy (np. polowania, relacji intymnej, tworzenia koalicji politycznej).

W oceanie informacji, w których jesteśmy zanurzeni, jedne z nich są bardziej cenne od innych. Egzystencja w grupie sprawia, że mamy do czynienia z ciągłym napływem nowych danych, nowych twierdzeń/opinii dotyczących konkretnych tematów. Te dane, które są dla danego człowieka najważniejsze, określane są mianem ,informacji strategicznych”.

\footnotetext{
${ }^{35}$ Tamże, s. 122.
} 
Informacja strategiczna jest częścią zbioru informacji dostępnych w danej chwili (dla określonego podmiotu i w określonej sytuacji), która pobudza systemy myślowe, odpowiedzialne za harmonijne relacje społeczne. [...] Mówiąc, że dana sytuacja jest strategiczna, stwierdzamy, że została przetworzona jako strategiczna przez systemy kojarzeniowe uczestniczące $\mathrm{w}$ relacjach społecznych jednostki ${ }^{36}$.

Te najważniejsze dla ludzi informacje mają jeszcze jedną niezwykle ważną cechę: nie są z góry dane, a dostęp do nich nie jest pełny. W relacjach społecznych nie możemy wiedzieć wszystkiego o wszystkich dla nas istotnych kwestiach - nie mamy wglądu do umysłu drugiej osoby, nie wiemy, jaką wiedzę na nasz temat posiada inna jednostka. Boyer określa tę cechę mianem "dostępu niezupełnego"37.

Jaki jest związek pomiędzy tymi faktami a wierzeniami religijnymi? Znowu okazuje się, że istnieje pewna prawidłowość dotycząca wyobrażeń istot nadprzyrodzonych. Boyer używa w tym miejscu pojęcia „istot strategicznych", aby określić wyobrażenie charakteryzujące się przekonaniem, że byty religijne posiadają informacje strategiczne. Zauważa też, że:

[w] powtarzających się na przestrzeni tysięcy lat cyklach przyswajania i przekazywania motywów kulturowych (bajek, opowieści, komentarzy do wydarzeń i sytuacji itp.) istoty strategiczne mają niewątpliwie przewagę w procesie selekcji, co wystarcza, by wyjaśnić, dlaczego pojawiają się częściej od innych ${ }^{38}$.

Dlaczego więc zakładamy, że istoty nadprzyrodzone mają swobodny dostęp do informacji strategicznych (szczególnie informacji strategicznych dotyczących relacji społecznych)? Otóż w sytuacji ciągłego poszukiwania danych, w tym przede wszystkim tych strategicznych, jednostka ludzka jest znacznie bardziej podatna na przyjęcie wiary w istnienie bytu nadprzyrodzonego, który taką wiedzę może posiadać, niż takiego, który niczego nie wie. Pojęcie takiego bytu pobudza znacznie więcej systemów kojarzeniowych, a (jak wspomniałem już w pierwszej części artykułu ${ }^{39}$ ) to właśnie

\footnotetext{
${ }^{36}$ Tamże, s. 153-154.

${ }^{37}$ Zob. tamże, s. 155.

${ }^{38}$ Tamże, s. 165.

${ }^{39}$ Zob. pozycje wskazane w przypisach 21 i 22.
} 
oddziaływanie pojęcia/idei na systemy kojarzeniowe decyduje o jego przyswajalności. Idea istoty nadprzyrodzonej posiadającej informacje strategiczne w sytuacji ciągłych poszukiwań informacji strategicznych jest praktycznie niemożliwa do zignorowania przez ludzkie systemy kojarzeniowe.

W ten sposób przechodzimy do ostatniej cechy bytów religijnych, która wymaga wyjaśnienia - kwestii relacji wobec nich: prób kontaktowania się z nimi, składania im darów czy modlenia się do nich. Zdecydowanie przeważają wierzenia w duchy, bóstwa czy przodków obserwujących relacje społeczne wewnątrz grupy, w związku z tym oceniających ludzkie relacje: czy są poprawne, niepoprawne - złe lub dobre w wymiarze moralnym. Z drugiej strony ludzie już od najmłodszych lat wykazują posiadanie intuicji moralnych, które są odpowiednikiem uniwersalnego przekonania o tym, co jest dobre lub złe niezależnie od punktu widzenia. Jaki jest związek pomiędzy tymi dwoma informacjami? Otóż idee religijne w pewien sposób „wykorzystują" nasze intuicje moralne - byt nadprzyrodzony, który posiada informacje strategiczne i jednocześnie jest zainteresowany ludzkimi relacjami społecznymi pobudza więcej systemów kojarzeniowych niż taki, który posiada wiedzę, ale ludzie go nie interesują.

Musimy przy tym pamiętać, że ludzie „nie rozumieją” zasad funkcjonowania środowiska społecznego, w którym żyją. W środowisku tym może dochodzić do nieograniczonej liczby sytuacji interpretowanych jako „dobre” lub „złe” - społeczność stanowi zarówno źródło ochrony jaki i zagrożenia. Jednocześnie doskonale wiemy, że ludzie działają intencjonalnie - zakładanie intencjonalności jest jedną z najbardziej podstawowych intuicji umożliwiających zdobywanie wiedzy i przyswajanie informacji. I dlatego też każda niezwykła sytuacja społeczna prowokuje interpretację przyczynową: to „ktoś” coś zrobił, nie zaś stało się „samo”. Warto zwrócić uwagę, jak często sami tak postępujemy na co dzień. Samochód zepsuł się „specjalnie”, gdy bardzo mi się śpieszyło. Drukarka „celowo” nie drukuje. Jak widać pierwotne intuicje są niejako wytwarzane w nas automatycznie. Tego typu hipoteza tłumacząca wydarzenie z reguły rozwija się niezależnie od wyobrażeń istot nadprzyrodzonych, ale niezwykle szybko może się ona z nią połączyć, jako że w ten sposób określony zostaje „ktoś”, a z drugiej strony określoną moc uzyskuje sama istota ${ }^{40}$.

\footnotetext{
${ }^{40}$ Zob. tamże, s. 201.
} 
Wracając do intuicji moralnych: każą nam one konkludować, iż posiadanie wszystkich informacji strategicznych na temat konkretnego wydarzenia pozwoliłoby uzyskać odpowiedź, co jest dobre, a co złe. Z tego wynika, że istoty nadprzyrodzone postrzegamy jako istoty, które posiadają natychmiastowy ogląd sytuacji i dzięki temu wiedzą, co jest dobre, a co złe. Odwraca to odwieczne przekonanie, jakoby religia dała początek moralności, jakby była jej jedynym źródłem. Jak podkreśla Boyer: „wbrew przypuszczeniom, religia nie była moralnością". To specyficzny sposób funkcjonowania naszego umysłu i „nasza intuicyjna refleksja moralna przygotowuje nas do przyjęcia pewnych idei religijnych, ich zachowania i przekazywania" ${ }^{41}$.

W ten sposób ukazane zostały przyczyny oraz mechanizmy powstania wierzeń religijnych - wyjaśnienie, którego dostarczyła nam antropologia i psychologia kognitywna zastosowane przez Pascala Boyera. Jak sam autor stwierdza:

Stworzyliśmy [...] bogów po części dlatego, że mamy umysł, który pozwala na istnienie społeczeństwa, jednak nie do końca umiemy zrozumieć jak ono funkcjonuje $e^{42}$.

Czyli „sekret” tworzenia idei religijnych tkwi w mechanizmach ludzkiego umysłu - w systemach myślowych, które człowiek posiada całkowicie niezależnie od religii. Idee religijne poniekąd „posługują się” systemami skojarzeniowymi, intuicjami moralnymi, intuicjami odnośnie istot żywych itd. W ten sposób można stwierdzić, iż wierzenia religijne „wykorzystują" specyficzne zdolności umysłowe. Boyer podkreśla, iż wspólnych cech religii nie odnajdziemy badając ich przedmiot, badając rytuały, ale zapominając o wierzącym. To w wierzącym znajduje się odpowiedź na pytanie, dlaczego powstały wierzenia religijne. Jednakże badania antropologów, psychologów, socjologów i innych naukowców dotyczące religii pozwalają na znacznie lepsze zrozumienie, dlaczego konkretne mechanizmy umysłowe wytworzyły pewien typ wierzeń religijnych. Nie dziwi też, dlaczego Boyer zaznacza, że takie zrozumienie religii od stosunkowo niedawna jest możliwe. Dopiero bowiem od niedawna ludzki umysł przestał być traktowany jako

\footnotetext{
${ }^{41}$ Tamże, s. 202.

${ }^{42}$ Tamże, s. 34.
} 
encyklopedia, a zaczął jako zestaw skomplikowanych systemów myślowych, funkcjonujących najczęściej poza ludzką świadomością. A przecież to właśnie:

wykorzystanie bogactwa systemów myślowych wyjaśnia przyczyny istnienia idei religijnych oraz ich kulturowego „sukcesu”; tłumaczy również, dlaczego ludzie uznają je za „wiarygodne”, w jaki sposób religia pojawia się na dziejowej scenie ${ }^{43}$.

Zgodnie z celem założonym na początku tego artykułu dokonana została analiza koncepcji pochodzenia religii i korzeni wierzeń religijnych sformułowanej przez francuskiego antropologa Pascala Boyera. Scharakteryzowane zostały najważniejsze elementy teorii Boyera opierającej się na psychologii kognitywnej i filozofii umysłu. W artykule wytłumaczona została także stosowana przez naukowca terminologia, w tym między innymi pojęcia „systemów kojarzeniowych”, „informacji strategicznych” oraz „kategorii ontologicznych". W artykule została również przedstawiona argumentacja Pascala Boyera ukazująca związek pomiędzy sposobem funkcjonowania ludzkiej pamięci/mózgu oraz powstaniem i rozwojem wierzeń/idei religijnych.

\section{GENESIS OF RELIGION IN THE LIGHT OF ANTHROPOLOGY AND COGNITIVE PSYCHOLOGY. PASCAL BOYER'S THESIS}

\section{SUMMARY}

The diversity of religious beliefs still surprises even scholars most familiar with these phenomena. What is most surprising is the sheer number of practices that reflect relations between deities and men - ranging from "devotion", „cooperation", to trying to "trick" deities. There have been many theories explaining the cause of these relations and the diversity of religious beliefs including the simplest, that these relations are true and reflect an ontological order.

\footnotetext{
${ }^{43}$ Tamże, s. 299.
} 
Leaving the question regarding the existence of supernatural beings aside, we're still left with a very interesting issue of human beliefs. Why do we have such different beliefs? Why are we so attached to them? Do they have anything in common? What were the origins of religious beliefs? Did they changed through time?

Pascal Boyer, French anthropologist studying the human mind and the process of learning among other issues tries to answer these, and other questions. He bases his answers on scientific researches of other scholars anthropologists, evolutionary biologists, cognitive psychologists and linguists. Boyer employs researches from such different scientific fields to find a new and very interesting way to try to reach the origins of religious beliefs, to reconstruct the process of forming beliefs concerning the metaphysical/non-physical world. He also tries to explain the nature of relations between men and deities. As a result of his efforts he created a theory explaining beliefs and religious behaviors that refers only to the mechanisms of human brain, and this theory is the subject of this article.

\section{KEYWORDS}

anthropology, cognitive psychology, explaining religion, nature of religious beliefs, origins of beliefs, Boyer P. 